\title{
Use of a new skin colour measurement method for the investigation of relationship between skin and tooth colour
}

\section{Purpose}

There is conflicting information about the relationship between tooth color and skin color in the literature. The aim of the present study was evaluation of the correlation between $\mathrm{L}, \mathrm{a}, \mathrm{b}$ values of skin and tooth shade using a new skin color measurement method.

\section{Materials and Methods}

CIELab values of teeth were obtained through measurements from the middle third of the labial surfaces on central incisors of individuals using a clinical spectrophotometer. CIELab values of the skin were measured through facial images using a software which was manufactured for present study. A statistical analysis program (SAS 9.4) was used for the analysis of the data. Kolmogorov-Smirnow test, t-test, and multivariate regression analysis were used to evaluate the data $(\alpha=0.05)$.

\section{Results}

Correlations between variables revealed that while the lowest and statistically insignificant correlations were observed with $a^{*}$ values of the skin, significant correlations did not exceed moderate level $(p<.05)$. When considering regression analysis results, $b^{*}$ values of the skin had a statistically significant effect in describing $b^{*}$ values of the tooth, while $L^{*}$ and $a^{*}$ values of the skin were observed to be insufficient in describing $L^{*}$ and $a^{*}$ values of the teeth.

\section{Conclusion}

Results of this study suggest that different significant correlations were observed between the skin and tooth color for different $L^{*}, a^{*}$, and $b$ parameters $(p<0.05$ and $p<0.01$ ). The results indicated that skin color can be used for tooth color selection in case of loss of natural teeth or when discoloration is present on existing teeth.

Keywords: Shade selection, Tooth shade, Skin colour, CIELab, Esthetics

\section{Introduction}

In prosthetic dentistry, esthetics of final restoration is one of the most important factors influencing the success of therapy. Dental treatment should be in harmony with the rest of the face, and a life-like appearance which is acceptable by the patient should be aimed. ${ }^{1,2}$ Selection of the correct tooth shade is one of the leading factors for an acceptable esthetics. Presence of teeth mostly provides convenience in selecting tooth shade. However, internal and external factors may influence the tooth shade; teeth may not have a natural appearance, and therefore, it may be hard to identify color using present teeth..$^{3,4}$ Selection of tooth shade may become even more difficult for the clinicians when there is no tooth to be used as reference. In these situations, selection of tooth shade may more subjective, and accordingly, some methods to overcome this issue were studied in the past and published. ${ }^{5,6}$ Other characteristics of the patients

\author{
Nurullah Türker ${ }^{1} \mathbb{D}$, \\ Ulviye Şebnem \\ Büyükkaplan² $\mathbb{D}^{\text {, }}$ \\ Işın Kürkçüoğlư ${ }^{3}$ (D), \\ Burak Yılmaz ${ }^{4}$
}

ORCID IDs of the authors: N.T. 0000-0003-4020-684X. U.Ş.B. 0000-0002-4962-2930; I.K. 0000-0002-2750-8977; B.Y. 0000-0002-7101-363X

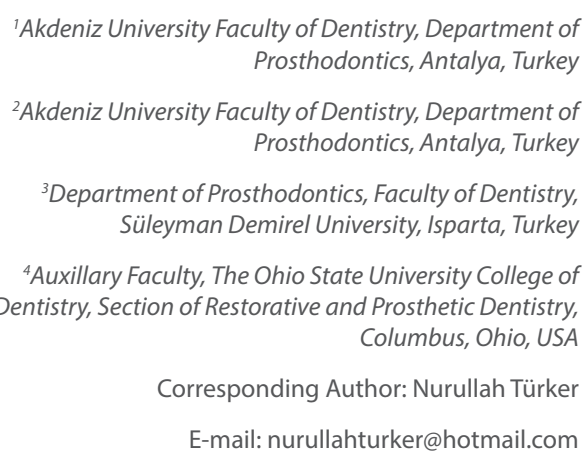

Received: 29 July, 2019 Revised: 10 September, 2019 Accepted: 18 October, 2019

DOI: $10.26650 /$ eor.20200090 
can be utilized for tooth shade selection in these situations. Some previous studies have reported that individual's eye, skin, hair color, and factors like sex and age can be used when selecting the tooth shade..$^{5-7}$

Some studies has indicated that tooth shade of women is lighter than men [8-10]. Some others reported that teeth with darker shade should be preferred for elderly individuals. ${ }^{11,12}$ A correlation was determined between hair color and tooth shade even if it was poor. ${ }^{7}$ While a significant correlation was observed in some studies investigating the correlation between the skin color and tooth shade, some studies reported no correlation. $5,7,10$

Different methods are used to determine the skin or tooth shade. While some researchers preferred using shade guides and various classifications providing more subjective data, and some others used computer programs and digital instruments to determine the color. ${ }^{11,13-16}$ The methods used in studies on a delicate issue like colorimetry are critical in terms of obtaining true and precise results. Digital methods were used to obtain the values that belong to both skin and teeth, however, a well-accepted method for skin color measurement has not been reported in the literature previously.

The aim of this study was to investigate any correlation between $L^{*}, a^{*}, b^{*}$ values of skin and tooth shade considering the gender using a novel color measurement technique. The null hypothesis was that the tooth and skin color would not be in a correlation.

\section{Materials and Methods}

This study was conducted on 149 dental students (67 male, 82 female, age range 18-23 and mean age of $20.8 \pm$ 2). Ethics committee approval and informed consent of all volunteers were received for the study (Decision Number: 70904504/335).

Individuals who had completely erupted maxillary right central incisors without decay and restoration, no skin disorder, and no postoperative facial cicatrix and individuals who did not undergo any color changing procedure on the face or skin were included in the study. Individuals who had restored teeth, teeth undergoing root canal therapy, teeth with internal or external discoloration, and who were smokers were excluded from the study.

Recommendations from previous studies were followed to design the image capturing technique for teeth and face in this study. ${ }^{14,17,18}$ Two weeks before the shade measurements of teeth, the test teeth were cleaned with polishing brush and polishing paste attached to a low-speed hand piece. Measurements were made from the middle third of labial surfaces of right maxillary central incisors of individuals using a clinical spectrophotometer (VITA Easyshade Advance, VITA Zahnfabrik) and according to the instructions of the manufacturer. CIE L*a*b* values were recorded.

Facial images were taken ${ }^{14,18}$ A digital camera (Nikon D5200) with 24.2 megapixel resolution was used in the present study. The participants were asked to wash their faces gently and remove their make up before their photographs were taken. They were kept in an environment with normal room temperature for 20 minutes before the photographs were taken. Camera adjustments included a macrolens with focal length ranging from 90 to $120 \mathrm{~mm}$, shutter speed of $1 / 50$, and lens aperture of $f / 5$. Soft box light sources were used for illumination and an opaque white background was used. External light sources and ambient conditions were kept constant for all individuals. Before photographs were taken, eyeglasses, jewellery, and hat were removed. Images of frontal appearances were taken by ensuring individuals to pose when Frankfurt horizontal plane was parallel to the ground and midsagittal plane was perpendicular to the ground.

CIELab values of the skin were measured through facial images by using a software which was specially manufactured for present study. The software automatically selects three zones on the face including frontal, right, and left malar areas, and the measurement of excessive changes of color (rashes, moles, etc.) on the skin is also automatically excluded through a button in the interface of the software (Figure 1). Average of CIE L*, $\mathrm{a}^{*}$, and $\mathrm{b}^{*}$ values were taken automatically from approximately 100.000 separate points in total in selected zones, excluding blotchy areas. Using this method, it was aimed to prevent zonal skin color changes to deviate the results of the measurements. SkinL, Skina, Skinb and ToothL, Tootha and Toothb were the codes to represent the $L^{*}, a^{*}$ and $b^{*}$ values of skin and teeth.

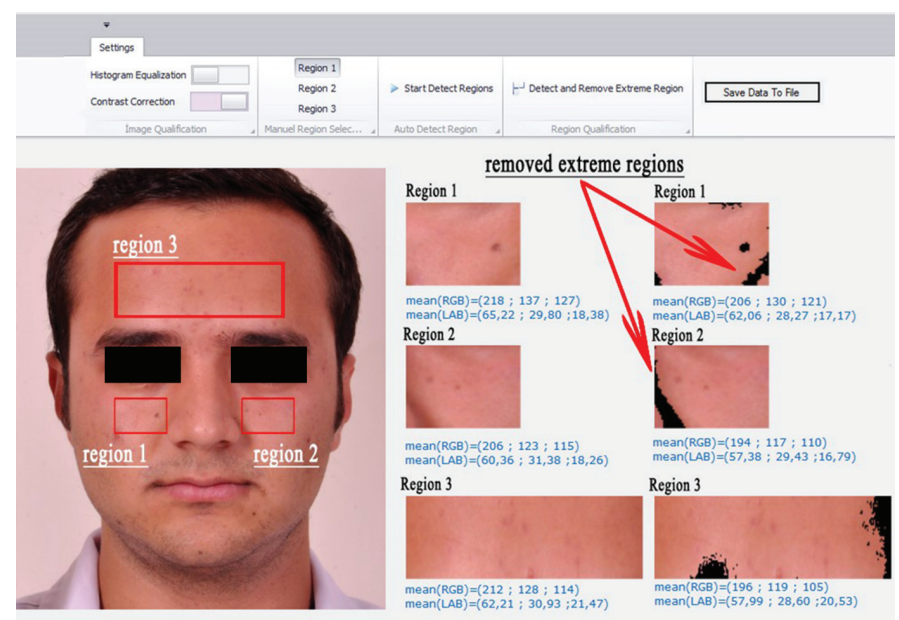

Figure 1. Use of the computer software to obtain CIELab values of skin color.

\section{Statictical analysis}

Descriptive statistics and t-tests were used for $L^{*}, a^{*}$, and, $b^{*}$ parameters of the skin and tooth color, and regression and correlation analysis were performed to reveal any correlation between them. Regression analysis was performed between the components (coordinates) which define the same properties of the color of the skin and the teeth. Regression analysis was also performed when values which define different chromatic properties were highly correlated A statistical software was used for all analyzes (SAS 9.4).

\section{Results}

Table 1 displays overall data of dependent and independent variables of individuals, descriptive statistics for male and females, and the results of t-test. According to these results, significant differences were observed with respect to gender between mean values of skinL, skinA, skinB, and toothA $(p<0,01)$. 
Table 2 displays the correlation between dependent (toothL, toothA, and toothB) and independent (skinL, skinA, and skinB) variables for males and females together, males, and females. There was high, moderate, no correlation between values of varying components. While the toothL component does not correlate with any other component, the toothA component was moderately correlated with the skinB component in for only males and for both genders together situation. $(p<.05)$. In addition, the toothA component had a correlation with the skinB component for males $(p<.05)$.

A high correlation was observed between the toothB component and the skinL component in all three cases of gender $(p<.01)$. While the toothb component for females correlated moderately with the skinb component $(p<.05)$, a high correlation was observed between these components for males and for both genders situation $(p<0.01)$.

Table 3 displays the regression analysis results between each of the dependent variables of tooth (toothL, toothA, and tooth $\mathrm{B}$ ) and corresponding independent variables of skin. Considering these results, skinB had a statistically significant effect in describing tooth $B(p<0.01)$, while skinL and skinA were observed to be insufficient in describing toothL and toothA ( $p>.05)$. This was associated with the fact that there was scarcely any correlation between skinL and toothL and skinA and toothA. The highest regression value was observed between the toothB and skinL parameters.

\section{Discussion}

Tooth shade is a complex phenomenon directly associated with the esthetics of the individual and involving subjective and objective factors. There is no sufficient scientific information about the correlation between tooth and skin color, information or reports in agreement. Some researchers stated that there was a reverse correlation between tooth and skin color; whereas, some others indicated a linear correlation. In the present study, it was observed that while a linear correlation was observed between some parameters of color, reverse correlation was observed in other parameters. There was a linear and significant correlation between $b^{*}$ values of the skin and the tooth. This result is similar to the result by Haralur et al. ${ }^{14}$ In contrast with this result, a powerful reverse correlation was observed between $L^{*}$ values of skin and $b^{*}$ values of tooth. This is in line with the results by Jahangiri et al. ${ }^{19}$ and N'Guessan et al. ${ }^{20}$ who found a reverse correlation between the tooth and skin color. Some researchers reported that there was no correlation between skin color and tooth color. ${ }^{8,10,21}$ The difference in

Table 1. Descriptive statistics and t-test results of variables of skin and tooth $\left({ }^{*} p<0.05,{ }^{* *} p<0.01\right)$

\begin{tabular}{lccccccccccccccccc}
\multicolumn{1}{c}{} & \multicolumn{4}{c}{ Male } & \multicolumn{1}{c}{ Female } & \multicolumn{4}{c}{ Male and Female } \\
\hline & $\mathbf{n}$ & Mean & Ss. & Min. & Max & $\mathbf{n}$ & Mean & Ss. & Min. & Max & n & Mean & Ss. & Min. & Max & P \\
\hline skinL & 67 & 56.103 & 3.762 & 46.293 & 67.493 & 82 & 59.447 & 4.790 & 48.163 & 73.867 & 149 & 57.943 & 4.653 & 46.293 & 73.867 & $0.000^{* *}$ \\
\hline skinA & 67 & 22.250 & 2.202 & 17.143 & 26.963 & 82 & 21.291 & 1.985 & 16.213 & 25.287 & 149 & 21.722 & 2.133 & 16.213 & 26.963 & $0.006^{* *}$ \\
\hline skinB & 67 & 15.327 & 2.617 & 8.820 & 21.817 & 82 & 14.220 & 2.662 & 5.647 & 20.511 & 149 & 14.718 & 2.691 & 5.647 & 21.817 & $0.012^{*}$ \\
\hline toothL & 67 & 84.369 & 3.387 & 71.667 & 90.200 & 82 & 85.124 & 2.490 & 80.100 & 91.133 & 149 & 84.785 & 2.941 & 71.667 & 91.133 & 0.119 \\
\hline toothA & 67 & -0.562 & 0.709 & -1.867 & 1.500 & 82 & -0.869 & 0.679 & -2.300 & 0.767 & 149 & -0.731 & 0.708 & -2.300 & 1.500 & $0.008^{* *}$ \\
\hline toothB & 67 & 19.503 & 3.525 & 10.700 & 27.100 & 82 & 18.344 & 4.196 & 5.233 & 26.833 & 149 & 18.866 & 3.938 & 5.233 & 27.100 & 0.074 \\
\hline
\end{tabular}

Table 2. Correlations between dependent (toothL, tooth $A$, and toothB) and independent (skinL, skinA, and skinB) variables ${ }^{*} p<0.05$, ${ }^{* *} p<0.01$ )

\begin{tabular}{lccc} 
& \multicolumn{3}{c}{ Male and Female } \\
\hline & skinL & skinA & skinB \\
\hline toothL & 0.00515 & -0.06765 & -0.04012 \\
\hline toothA & $-0.17089^{*}$ & 0.04513 & 0.08258 \\
\hline toothB & $-0.28683^{* *}$ & -0.06146 & $0.25561^{* *}$ \\
\hline & & Male \\
\hline toothL & -0.10784 & -0.05953 & 0.05026 \\
\hline toothA & $-0.26698^{*}$ & -0.07481 & $0.16683^{*}$ \\
\hline toothB & $-0.31778^{* *}$ & -0.09817 & $0.29397^{* *}$ \\
\hline & & Female \\
\hline toothL & 0.00829 & -0.01698 & -0.08488 \\
\hline toothA & 0.00594 & 0.06360 & -0.06620 \\
\hline toothB & $-0.21927^{* *}$ & -0.09944 & $0.19292^{*}$ \\
\hline
\end{tabular}

Table 3. Results of regression analysis between each of dependent variables of tooth (tooth L, toothA, and toothB) and corresponding independent variables

\begin{tabular}{ccc}
$\begin{array}{c}\text { Parameter } \\
\text { Estimation }\end{array}$ & $\begin{array}{c}\text { Standard } \\
\text { error }\end{array}$ & t value \\
\hline
\end{tabular}

Dependent toothL

\begin{tabular}{lcccc}
\hline Intercept & 84.5963 & 3.03048 & 27.92 & 0.0001 \\
\hline skinL & 0.0032 & 0.05213 & 0.06 & 0.9503 \\
\hline Dependent toothA & & & \\
\hline Intercept & -1.05606 & 0.59664 & -1.77000 & 0.07880 \\
\hline skinA & 0.01497 & 0.02734 & 0.55000 & 0.58470 \\
\hline
\end{tabular}

Dependent toothB

\begin{tabular}{lcccc}
\hline Intercept & 13.3588 & 1.74611 & 7.65000 & 0.000 \\
\hline skinB & 0.3742 & 0.11672 & 3.21000 & 0.00170 \\
\hline \multicolumn{4}{l}{ Dependent toothL } \\
\hline Intercept & 32,9317 & 3,8871 & 8,4718 & 0,000 \\
\hline SkinL & $-0,2427$ & 0,0668 & $-3,6301$ & 0,000 \\
\hline
\end{tabular}


those results might be associated with varying methods used in different studies. In several previous studies, color records were visually made using shade guides or various classifications for skin and tooth color selection. ${ }^{11,15,16} \mathrm{In}$ visual method, skin color or tooth shade is generally categorized. Color selection depends on subjective assessment of researcher and ambient light may directly influence the type of color selection. These limitations in visual color selection might have affected the these study results. In the present study, digital methods were preferred when measuring both tooth and skin color, and the effect of light was minimized by eliminating the subjective factors. Haralur et al. ${ }^{14}$ used a spectrophotometer, which is not affected from external lights when measuring tooth color and facial images when measuring the color skin. Seck et al., ${ }^{13}$ on the other hand, used facial images in both processes. Researchers compared the results by taking color value from a few points determined on the face in photographs. When human skin was examined closely, excessive color changes were observed on small areas. Therefore, it is possible to obtain different $\mathrm{CIE}$ Lab values on every pixel where color sample is taken. In order to avoid this problem, a new software was used when obtaining facial color on the images in the present study. The software gives the average of $L^{*}$, $a^{*}$ and $b^{*}$ values taken from approximately 100.000 points by excluding severe color changes detected on the face from the measurement.

While the t-test results obtained in our study revealed a significant difference for gender in terms of mean values, no highly significant differences were found in the correlation analysis between teeth and skin color. When the results of tooth-skin correlation of male, female, male and female were examined separately, it was observed that the significances were similar (Table 2). There was no effect of gender found in describing tooth color and skin color correlation.

When the results from the regression analysis were examined, $b^{*}$ values of skin had a statistically significant effect in explaining the $b^{*}$ values of tooth. The highest correlation was observed between the $b^{*}$ values of the tooth and the $L^{*}$ values of the skin, which define the different characteristics of the color (Table 2). This was confirmed by the results of the regression analysis (Table 3 ). These findings indicate that skin color data which were digitally obtained are likely to be used for estimating tooth shade through various mathematical equations.

In the present study, skin color measurements were performed on digital images obtained by standardizing the lighting conditions. The use of standard light is one of the main limitations of the current and similar previous studies. ${ }^{13,14}$ However, in this study, color determination from approximately 100,000 different points and an average CIELab value is remarkable for skin color standardization. Further studies should investigate whether different lighting conditions have an impact on the relationship between skin color and tooth color.

This study focused on potential correlations between the color components of skin and teeth. The accuracy of the system will be evaluated and reported in future studies. The results obtained in the present study may help researchers to have a better understanding about the correlation between tooth and skin color. Xiao et al. described a new software process for measuring skin color. ${ }^{22}$ In this respect, the results of this study should be interpreted considering that a new, specifically manufactured software was used and different software may lead to different results. Further studies are needed to evaluate the effect of age on the correlation between tooth and skin color.

\section{Conclusion}

Within the limitations of the present study, different significant correlations were observed between the skin and tooth color for different CIELab parameters. When the color components of the skin and teeth are evaluated separately, the $b^{*}$ values of the teeth and the $L^{*}$ and $b^{*}$ values of the skin are highly correlated. The results indicated that some CIELab parameters of the skin color may be used for tooth color selection in case of loss of natural teeth or when existing teeth are discolored.

Türkçe Özet: Cilt ve diş rengi arasındaki ilişkinin araştırılmasında yeni bir cilt rengi ölçüm yönteminin kullanılması. Amaç: Literatürde diş rengi ile cilt rengi arasındaki ilişki hakkında çelişkili bilgiler vardır. Bu çalışmanın amacı, cilt ve dişlere ait $L, a, b$ değerleri arasındaki ilişkinin yeni bir cilt rengi ölçüm yöntemi kullanılarak değerlendirilmesidir. Gereç ve Yöntem: Dişlere ait CIELab değerleri, klinik spektrofotometre kullanılarak bireylerin orta keser dişlerinin labial orta üçlüsünden yapılan ölçümlerle elde edildi. Cilde ait CIELab değerleri, bu çalışma için özel olarak üretilmiş bir yazılım kullanılarak bireylerin fotoğrafları üzerinden ölçüldü. Verilerin analizi için bir istatistiksel analiz programı (SAS 9.4) kullanıldı. Verilerin değerlendirilmesinde Kolmogorov-Smirnow testi, t-testi ve çok değişkenli regresyon analizi kullanıldı $(a=0.05)$. Bulgular: Değişkenler arası korelasyonlar deri rengine ait $a^{*}$ değerleri için düşük ve istatistiksel olarak anlamlı değilken, diğer değişkenler arası görülen anlamlı olan korelasyonların ise orta düzeyi geçmediği gözlendi $(p<.05)$. Regresyon analizi sonuçları dikkate alındığında, cilde ait $b^{*}$ değerleri ile dişlere ait $b^{*}$ değerleri istatistiksel olarak anlamlı düzeyde tanımlarken, cilde ait $L^{*}$ ve $a{ }^{*}$ değerlerinin dişlere ait $L^{*}$ ve $a{ }^{*}$ değerlerinin tanımlanmasında yetersiz olduğu gözlendi. Sonuç: Bu çalışmanın sonuçları, $L^{*}, a^{*}$ ve $b^{*}$ parametreleri için cilt ve diş rengi arasında farklı korelasyonların bulunduğunu göstermiştir $(p<0.05$ ve $p<0.01)$. Sonuçlar, doğal dişlerin tamamen kaybedilmesi veya mevcut dişlerde renk değişikliği olması durumunda, cilt renginin diş rengi seçimi için kullanılabileceğini göstermektedir. Anahtar Kelimeler: renk seçimi, diş rengi, ten rengi, CIELab, estetik

Ethics Committee Approval: Ethics committee approval and informed consent of all volunteers were received for the study (Decision Number: 70904504/335).

Informed Consent: The informed consents were provided by the participants.

Peer-review: Externally peer-reviewed.

Author contributions: NT, USB, IK, and BY designed the study. NT and USB participated in generating the data for the study. NT participated in gathering the data for the study. NT, USB, IK, and BY participated in the analysis of the data. NT and USB wrote the majority of the original draft of the paper. NT, USB, IK, and BY participated in writing the paper. All authors approved the final version of this paper.

Conflict of Interest: The authors has no conflict of interest to declare.

Financial Disclosure: The study was supported by the Scientific Research Council of Turkey (TÜBITAK) (Grant number 114E653). 


\section{References}

1. Rangarajan V, Padmanabhan T. Textbook of Prosthodontics-E Book. Elsevier Health Sciences 2017. p:797.

2. Goldstein RE. Esthetics in dentistry. 2nd ed. Hamilton: B.C. Decker Inc 2014. p: 187-206.

3. Krastl G, Allgayer N, Lenherr P, Filippi A, Taneja P, Weiger R. Tooth discoloration induced by endodontic materials: a literature review. Dent traumat 2013;29:2-7. [CrossRef]

4. Zimmerli B, Jeger F, Lussi A. Bleaching of nonvital teeth. Schweiz Monatsschr Zahnmed 2010;120:306-13.

5. Vadavadagi SV, Kumari KH, Choudhury GK, Vilekar AM, Das SS, Jena D, Kataraki B. Prevalence of tooth shade and its correlation with skin colour-A cross-sectional study. Journal Clin Diag Res 2016;10:ZC72. [CrossRef]

6. Kurt A, Isik-Ozkol G. Conventional methods for selecting form, size, and color of maxillary anterior teeth: Review of the literature. Eur J Prosthodont 2015;3:57-63. [CrossRef]

7. Lagouvardos PE, Tsamali I, Papadopoulou C, Polyzois G. Tooth, skin, hair and eye colour interrelationships in Greek young adults. Odontology 2013;101:75-83. [CrossRef]

8. Gozalo-Diaz D, Johnston WM, Wee AG. Estimating the color of maxillary central incisors based on age and gender. J Prosthet Dent 2008;100:93-8. [CrossRef]

9. Odioso L, Gibb R, Gerlach R. Impact of demographic, behavioral, and dental care utilization parameters on tooth color and personal satisfaction. Compend Contin Educ Dent Suppl (Jamesburg, NJ: 1995) Supplement, 1999S35-41; quiz S43.

10. Esan T, Olusile A, Akeredolu P. Factors influencing tooth shade selection for completely edentulous patients. J Contemp Dent Pract 2006;7:80-7. [CrossRef]

11. Tuncdemir AR, Gungor AY, Kahraman B. The relationship of some patients factors with shade of their teeth measured by spectrophotometry in Turkish people. Pak J Med Sci 2012;1:67-70.

12. Solheim T. Dental color as an indicator of age. Gerodontics 1988;4:114-8.

13. Seck A, Guèye $M$, Dieng L, Mbodj EB, Ndiaye C, Seck MT, Ngom $\mathrm{PI}$. Correlations between colorimetric parameters of teeth, eyes and skin. Perspectives in the choice of tooth shade for complete denture. Odontostomatol Trop 2013;36:17-25.

14. Haralur SB, Dibas AM, Almelhi NA, Al-Qahtani DA. The tooth and skin colour interrelationship across the different ethnic groups. Int J Dent 2014;1:1-6. [CrossRef]

15. Sharma V, Punia V, Khandelwal M, Punia S, Rao L. A study of relationship between skin color and tooth shade value in Population of Udaipur, Rajasthan. Int J Dent, 2010;2:26-9.

16. Sabherwal RS, Gonzalez J, Naini FB. Assessing the influence of skin color and tooth shade value on perceived smile attractiveness. J Am Dent Assoc 2009;140:696-705. [CrossRef]

17. Swamy RS, Most SP. Pre-and postoperative portrait photography: standardized photos for various procedures. Facial Plast Surg Clin North Am 2010;18:245-52. [CrossRef]

18. Khavkin J, Ellis DA. Standardized photography for skin surface. Facial Plast Surg Clin North Am 2011;19:241-6. [CrossRef]

19. Jahangiri L, Reinhardt SB, Mehra RV, et al. Relationship between tooth shade value and skin color: an observational study. J Prosthet Dent 2002;87:149-52. [CrossRef]

20. N'Guessan K, N'Dindin A, Koffi N, Assi KD, Odi AL. The complexion and color of teeth in a Black African population. Apropos of a sample of 240 subjects. Odontostomat Trop 2001;24:25-8.

21. Hassel AJ, Nitschke I, Dreyhaupt J, Wegener I, Rammelsberg P, Hassel JC. Predicting tooth color from facial features and gender: results from a white elderly cohort. J Prosthet Dent 2008;99:1016. [CrossRef]

22. Xiao K, Zhu Y, Li C, Connah D, Yates JM, Wuerger S. Improved method for skin reflectance reconstruction from camera images. Optics Express 2016;24:14934-50. [CrossRef] 